\title{
Serum Vitamin D levels in Chronic Obstructive Pulmonary Disease
}

\author{
Kumar $A^{1}$, Tandon $S^{2}$, Nagdeote $S T^{3}$, Sharma $K^{4}$, Shrikhande $A^{5}$, Gopal $K^{6}$ \\ ${ }^{1}$ Dr. Ajay Kumar, PG Student, ${ }^{2}$ Dr. Sanjay Tandon, Professor and Head, ${ }^{3}$ Dr. S T Nagdeote, Professor, ${ }^{4}$ Dr. Kapil \\ Sharma, Assistant Professor, ${ }^{5}$ Dr. Akash Shrikhande, Assistant Professor, ${ }^{6}$ Dr. Krishna Gopal, PG Student; all authors are \\ affiliated with Department of Pulmonary Medicine, People's College of Medical Sciences \& RC, Bhanpur, Bhopal, MP, \\ India.
}

Address for Correspondence: Dr. Sanjay Tandon, Department of Pulmonary Medicine, Peoples College of Medical Sciences \& RC, Bhanpur, Bhopal. Email: drajay86.ak@gmail.com

\begin{abstract}
Introduction: Lower serum $25(\mathrm{OH})$ Vitamin D is associated with decreased lung function in healthy population and various lung disease. Information on the relationship of levels of serum $25(\mathrm{OH})$ Vitamin D with severity of Chronic Obstructive Pulmonary Disease (COPD) is important in standardizing the treatment, in planning appropriate follow up and improving quality of life. This study also warranted further trial to assess the effect of serum $25(\mathrm{OH}) \mathrm{vitamin} \mathrm{D}$ on morbidity and mortality in COPD patients. Material and Methods: It was a prospective (observational), cross-sectional study which included all patients with Chronic Obstructive Pulmonary Disease (COPD) attended the Department of Pulmonary Medicine, People's College of Medical Sciences \& RC, Bhopal, over a period of 1 year 6 months. Results: The mean serum $25(\mathrm{OH})$ vitamin D level in COPD patients was $27.86 \pm 16.47 \mathrm{ng} / \mathrm{ml}$. There was no significant difference in serum $25(\mathrm{OH})$ vitamin D between patients in different age groups. The serum $25(\mathrm{OH})$ vitamin D levels varied significantly between different GOLD stages and different mMRC dyspnea grades. The patient who had a history of admission for twice or more in the past 1 year had a lower mean serum $25(\mathrm{OH})$ vitamin $\mathrm{D}$ level as compared to patient with just one or no hospitalization in the past. Conclusion: Decrease serum $25(0 \mathrm{H})$ vitamin D levels were associated with increase airway obstruction.
\end{abstract}

Keywords: Chronic Obstructive Pulmonary Disease (COPD), mMRC, FEV1\%, Serum 25 (OH) vitamin D, Acute Exacerbation, pack years, socioeconomic, 6 minute walk test.

\section{Introduction}

The role of $25(\mathrm{OH})$ vitamin $\mathrm{D}$ in preserving skeletal integrity is well known. However, it has become evident that $25(\mathrm{OH})$ vitamin $\mathrm{D}$ deficiency is associated with increased risk of chronic diseases like cancer, autoimmune diseases, infectious diseases, cardiovascular diseases and respiratory diseases [1].

Previous studies strongly suggest that $25(\mathrm{OH})$ vitamin $\mathrm{D}$ deficiency may be a risk factor for respiratory disease such as development of respiratory infections [2] and increasing asthmatic symptoms or asthma in childhood [3], [4]. National Health and Nutrition Examination Survey [NHANES-3] on general population $(n=14076)$

Manuscript received: $5^{\text {th }}$ February 2017

Reviewed: $14^{\text {th }}$ February 2017

Author Corrected: $20^{\text {th }}$ February 2017

Accepted for Publication: $27^{\text {th }}$ February 2017 in the United States suggest that lower levels of $25(\mathrm{OH})$ vitamin $\mathrm{D}$ were associated with a reduced level of lung function measured by forced expiratory volume in one second (FEV1) and forced vital capacity (FVC) [5]. Recent studies show that a substantial proportion of patients with chronic obstructive pulmonary disease have decreased $25(\mathrm{OH})$ vitamin D levels $(<20 \mathrm{ng} / \mathrm{mL})$ [1], [6], [7]. In one study of 262 COPD patients FEV1, body mass index (BMI), season of blood sampling and gene variants in the $25(\mathrm{OH})$ vitamin $\mathrm{D}$ binding gene were found to be significantly associated with $25(\mathrm{OH})$ vitamin D deficiency [1].

Obstructive lung disease by the year 2030 is expected to rank among the top five chronic diseases in term of global mortality and morbidity [8]. Deficiency of serum 
$25(\mathrm{OH})$ vitamin $\mathrm{D}$ in COPD patients is highly prevalent but correlation between serum $25(\mathrm{OH})$ vitamin D levels and severity of COPD is not yet well documented. It is reasonable to compare the levels of $25(\mathrm{OH})$ vitamin $\mathrm{D}$ with severity of COPD. In this current study we aimed to assess the association between level of serum $25(\mathrm{OH})$ vitamin $\mathrm{D}$ and severity of COPD. We also aimed to examine possible interaction by different variable such as 6 minute walk test, FEV1, mMRC grading, exacerbations frequency, Socioeconomic Status and body mass index. We hypothesized that low $25(\mathrm{OH})$ vitamin $\mathrm{D}$ level would be associated with increase severity of COPD and lower lung function.

\section{Material and Methods}

Study Population: All Patients with confirmed diagnosis of Chronic Obstructive Pulmonary Disease (COPD) presenting to the Department of Pulmonary Medicine, Peoples hospital and RC, Bhopal, who fulfill the study criteria were selected prospectively over a period of 1 year 6 months (November 2014 to April 2016). This was a prospective, cross-sectional study with sample size of 112 patients.

Procedure for Sampling: All the patients age 40 and above presenting to pulmonary medicine department, who fulfilled the COPD diagnostic criteria [8] according to the Global Strategy for the Diagnosis, Management, and Prevention of COPD (GOLD) were evaluated during a single visit that included a medical interview, physical examination, 6-MWT, BMI, CXR, ECG, laboratory test for $25(\mathrm{OH})$ vitamin $\mathrm{D}$ and spirometry.

Exclusion criteria were: (1) Patient of Obstructive Lung Disease other than COPD, (2) Patient of associated lung disease. e.g. presence of pulmonary infection, active pulmonary tuberculosis, pleural effusion, pulmonary emboli, pulmonary hypertension, (3) Concurrent reason for worsening of COPD symptoms; e.g. congestive heart failure, acute myocardial infarction, (4) Contraindication or inability to perform required tests, (5) Conditions associated with $25(\mathrm{OH})$ vitamin D metabolism, absorption e.g. hyperparathyroidism. (6) Use of medications for three or more consecutive months, which may interfere in $25(\mathrm{OH})$ vitamin $\mathrm{D}$ metabolism e.g. 25(OH) vitamin D supplements, thiazide diuretics, phenytoin, (7) Uncooperative patients or unwilling to give informed written consent.
Sample selection and data collection: Medical history was obtained through a questionnaire applied by a single investigator. Data obtained included age, gender, smoking history, previous history of exacerbations, socioeconomic history, BMI, uses of inhaled corticosteroid, season and dyspnea scale (mMRC). Smoking history was determined as current smoker, exsmoke and never smoked. Smoking intensity, expressed in pack-years which were number of cigarette packs per day per year of smoking. Patients who had stopped smoking less than 6 months prior to the evaluation were considered to have a current smoking history. In our study we have considered one cigarette equal to one bidi. Exacerbations history was based on participant response to question: " Did you had less than two episode of exacerbations in previous year"' (yes or no).

Here acute exacerbation was defined to patients as increased or new onset of more than one of the following: cough, expectorant, dyspnea, wheeze, chest tightness for at least 3 days and requiring hospitalization, antibiotics or systemic corticosteroids. Socioeconomic history was according to updated BG Prasad socioeconomic classification 2014 [10]. Inhaled corticosteroids data was based on questioner: " Have you in the past six month, used inhaled corticosteroid, consistently for more than two month ". Seasons were classified according to seasons of blood sample collection. \{Winter (Dec-March), Summer (Apr-June), Monsoon (July-Sep), Post monsoon (Oct-Nov) \} [11].

Modified Medical Research Council (mMRC) dyspnea scale was used according to guidelines to grade severity of dyspnea [12]. Blood sample for serum $25(\mathrm{OH})$ vitamin $\mathrm{D}$ measurements were collected by trained heath care worker and processed without delay. Serum $25(\mathrm{OH})$ vitamin D level were measured by a fully automated antibody-based CHEMILUMINESCENCE (CLIA) assay. Serum $25(\mathrm{OH})$ vitamin D level were the best marker of body vitamin D status (13).

We categorized according to widely used biological reference range, which was defined as deficiency as serum 25-(OH)D <20ng/ml, insufficiency between $20 \mathrm{ng} / \mathrm{ml}$ to $29 \mathrm{ng} / \mathrm{ml}$, sufficient between 30 to $100 \mathrm{ng} / \mathrm{ml}$ and toxic above $100 \mathrm{ng} / \mathrm{ml}$ (14). Spirometry was done by trained professional at screening station using Schiller sensors SP-260, also recommendations and criteria from the American Thoracic Society (ATS) were applied and followed. Schiller sensors SP-260 work on pneumotachometer method, was a complained with 
ATS 1994 standards. Instrument and biological quality control was conducted periodically via trained staff for quality assurance. Tests were performed in sitting position before and 20 minutes after $2.5 \mathrm{mg}$ Salbutamol given via nebulizer with a nose clip. Three to four trials were given. Best of all trial were included where expiration continued for $>6 \mathrm{~s}$ with acceptable flow/volume loop. FEV1 and FEV1/FVC parameter were used to diagnose COPD, whereas FEV1\% predicted were used in study for severity of COPD assessment. GOLD grouping [8] and GOLD severity staging [8] were done according to guideline. 6 Minute Walk (6MTW) Tests were performed according to standardized approach of ATS guidelines [15]. Limitation, contraindication, safety issues and quality assurance of the test was consider as priority.

Statistical Analysis: Statistical analysis was done using Statistical Package of Social Science (SPSS Version 20; Chicago Inc., USA). Data comparison was done by applying specific statistical tests to find out the statistical significance of the comparisons. Quantitative variables were compared using mean values and qualitative variables using proportions. Significance level was fixed at $\mathrm{P}<0.05$.

\section{Results}

We screened patients from November 2014 to April 2016 in the Department of Pulmonary Medicine, Peoples Hospital, Bhopal and found 112 patients met these inclusion and exclusion criteria. Among 112 patients 21 patients refused to participate in this study. From remaining, 7 were excluded because some of them were unable to perform spirometry due to restricted mouth opening (fibrosis, carcinoma) and others were unable to perform 6MWT (2 DVT, 1 Lower limb amputation). We excluded 2 patients as they did not allow us to draw blood sample. Out of remaining 82 patients 8 patients were excluded from further analysis due to missing data. Final analysis was done on 74 patients. Out of 74 patients 66 were males and mean age was 63 years. Mean Vitamin D level among population was $27 \mathrm{ng} / \mathrm{ml}$ and 6 were having positive smoking history.

\section{Table-1: Characteristic of the patients with COPD.}

\begin{tabular}{|c|c|}
\hline Characteristic & MEAN or Number \\
\hline Total Number of Patients (n) & 74 \\
\hline Age in Years(Mean) & $63.84 \pm 9.86$ \\
\hline Male:Female (Ratio) & $66: 8$ \\
\hline Pack Year, (Mean) & $29.81 \pm 15.60$ \\
\hline Vitamin D Level, [Mean (ng/ml)] & $27.86 \pm 16.47$ \\
\hline mMRC \# (Mean) & $2.57 \pm 0.49$ \\
\hline 6 Min Walk test (meter) & $228.96 \pm 151.61$ \\
\hline FEV1\% Predicted (Mean) & $50.88 \pm 16.30$ \\
\hline Smoking Status, [n(\%)] & $24(32.4 \%)$ \\
\hline Current Smoker (n) & $42(56.8 \%)$ \\
\hline Ex-Smoker (n) & $8(10.8 \%)$ \\
\hline Non-Smoker (n) & $6(8.1 \%)$ \\
\hline COPD^Severity [n(\%)] & $24(32.4 \%)$ \\
\hline Mild & $32(43.2 \%)$ \\
\hline Moderate & $12(16.2 \%)$ \\
\hline Severe & \\
\hline Very Severe & \\
\hline
\end{tabular}

*BMI - Body mass index, \#mMRC - Modified medical research council, ^COPD - Chronic obstructive pulmonary disease.

General Characteristics: Results were expressed using means \pm standard deviations. In our study, the mean FEV1 \% predicted was $50.88 \%$ and mean serum $25(\mathrm{OH})$ Vitamin D level was $27.86 \pm 16.47 \mathrm{ng} / \mathrm{ml}$ (Table 1). Mean age at 
presentation was $63.84 \pm 9.86$ years. Out of 74 patients, most (56) patients were in GOLD stage $2 \& 3$. Mean $25(\mathrm{OH})$ vitamin D level was highest $(59.33 \mathrm{ng} / \mathrm{ml})$ among stage 1 patients. Majority of patients $(56.8 \%)$ were ex-smoker and only $10.8 \%$ patients were non-smoker. The mean pack years were $29.81 \pm 15.60$.

Table- 2: Mean serum $25(\mathrm{OH})$ vitamin D levels in different age group in COPD patients.

\begin{tabular}{|c|c|c|c|c|c|}
\hline & & \multicolumn{2}{|c|}{ Vitamin D level(ng/ml) } & \multirow{2}{*}{$\begin{array}{c}\text { ANOVA 'F' } \\
\text { Value }\end{array}$} & $\begin{array}{c}\text { Significance 'p' } \\
\text { Value }\end{array}$ \\
\cline { 1 - 3 } Age Groups (Year) & Number & MEAN & SD & & \multirow{2}{*}{0.083} \\
40-59 year & 17 & 31.06 & 17.85 & \\
60-69 year & 33 & 31.30 & 14.18 & & \\
\hline 70-79 year & 17 & 19.94 & 13.54 & & \\
\hline
\end{tabular}

Age group: (Table 2) In our study, Mean 25(OH) vitamin D level was lower among older patients (>70 years) than younger patients (<69years). However, there was statistically no significant difference in $25(\mathrm{OH})$ vitamin $\mathrm{D}$ levels according to different age groups with a p value of 0.083 .

Table-3: Characteristics of patients according to GOLD staging.

\begin{tabular}{|c|c|c|c|c|c|c|}
\hline \multirow[t]{2}{*}{ Characteristic } & \multicolumn{4}{|c|}{ Gold Staging } & \multirow[t]{3}{*}{ F Value } & \multirow[t]{3}{*}{ pValue } \\
\hline & $\begin{array}{c}\text { Stage } 1 \\
n-6\end{array}$ & $\begin{array}{c}\text { Stage } 2 \\
n-24\end{array}$ & $\begin{array}{c}\text { Stage } 3 \\
n-32\end{array}$ & $\begin{array}{c}\text { Stage } 4 \\
\mathrm{n}-12\end{array}$ & & \\
\hline & Mean \pm SD & Mean \pm SD & Mean \pm SD & Mean \pm SD & & \\
\hline Age in Years & $55.17 \pm 8.68$ & $63.29 \pm 10.06$ & $63.63 \pm 8.51$ & $69.83 \pm 10.70$ & 3.347 & 0.024 \\
\hline Pack Year & $24.33 \pm 8.21$ & $23.67 \pm 14.05$ & $30.97 \pm 15.44$ & $41.75 \pm 15.57$ & 4.434 & 0.007 \\
\hline mMRC & $1.00 \pm 0.00$ & $2.13 \pm 0.33$ & $3.09 \pm 0.73$ & $3.58 \pm 0.90$ & 32.688 & 0.001 \\
\hline BMI & $22.83 \pm 4.11$ & $18.79 \pm 4.89$ & $18.91 \pm 4.36$ & $18.09 \pm 3.86$ & 1.663 & 0.183 \\
\hline $\begin{array}{l}6 \text { Min Walk test } \\
\text { (Meter) }\end{array}$ & $515.00 \pm 65.65$ & $347.71 \pm 69.80$ & $147.81 \pm 73.54$ & $64.83 \pm 34.91$ & 101.077 & 0.001 \\
\hline $\begin{array}{c}\text { Vitamin D Level } \\
(\mathrm{ng} / \mathrm{ml})\end{array}$ & $59.33 \pm 15.51$ & $36.17 \pm 10.35$ & $22.25 \pm 10.98$ & $10.50 \pm 4.10$ & 37.558 & 0.001 \\
\hline
\end{tabular}

COPD Severity: (Table 3) Mean Vitamin D level was highest among stage1 COPD patients and as severity increased, vitamin D level decreased. Stage 4 COPD patients had the lowest serum $25(\mathrm{OH})$ vitamin D levels. There was a negative correlation between COPD severity and vitamin D levels. The distribution of mean serum 25(OH) vitamin D according to severity of disease was statistically highly significant. $(\mathrm{p}=0.001)$

Table- 4: mean vitamin D level according to mMRC Dyspnea grade among COPD patients.

\begin{tabular}{|c|c|c|c|c|c|}
\hline \multirow{2}{*}{$\begin{array}{c}\text { mMRC Dyspnea } \\
\text { grade }\end{array}$} & & \multicolumn{2}{|c|}{ Vitamin D level(ng/ml) } & \multirow{2}{*}{$\begin{array}{c}\text { ANOVA 'F' } \\
\text { Value }\end{array}$} & $\begin{array}{c}\text { Significance 'p' } \\
\text { Value }\end{array}$ \\
\cline { 1 - 4 } & Number & MEAN & SD & & \\
Grade 1 & 9 & 52.00 & 19.69 & & \multirow{2}{*}{29.938} \\
\hline Grade 2 & 22 & 35.91 & 10.69 & \\
\hline Grade 3 & 26 & 22.31 & 10.18 & \\
\hline Grade 4 & 17 & 13.18 & 6.03 & \\
\hline
\end{tabular}

mMRC dyspnea grade: Out of 74 patients, most of the patients were in mMRC grade 2 and 3. Mean 25(OH) vitamin D level was highest among Grade 1 patients $(52 \mathrm{ng} / \mathrm{ml})$, with increasing mMRC, 25(OH) vitamin D level decreased. Mean serum $25(\mathrm{OH})$ vitamin D levels was lest $(13 \mathrm{ng} / \mathrm{ml})$ among grade 4 COPD patients. There was statistically highly significant negative correlation found between mMRC Dyspnoea grade and 25(OH) vitamin D level with $p$ value of 0.001 . 
Table- 5: Comparison of mean vitamin D level according to GOLD group among COPD patients.

\begin{tabular}{|c|c|c|c|c|c|}
\hline \multirow[b]{2}{*}{ Gold groups } & \multirow[b]{2}{*}{ Number } & \multicolumn{2}{|c|}{ Vitamin D level(ng/ml) } & \multirow[b]{2}{*}{$\begin{array}{l}\text { ANOVA } \\
\text { 'F' Value }\end{array}$} & \multirow[b]{2}{*}{$\begin{array}{c}\text { Significance } \\
\text { 'p' Value }\end{array}$} \\
\hline & & MEAN & SD & & \\
\hline Group A & 6 & 59.33 & 15.51 & \multirow[t]{4}{*}{39.260} & \multirow[t]{4}{*}{0.001} \\
\hline Group B & 24 & 36.17 & 10.35 & & \\
\hline Group C & 2 & 45.00 & 24.04 & & \\
\hline Group D & 42 & 17.81 & 8.74 & & \\
\hline
\end{tabular}

Mean vitamin 25 (OH) D levels: GOLD group were divided according to disease symptoms and risk. In our study out of 74 patients, maximum 42 were in GOLD group A and 24 were in group B. Mean 25(OH) vitamin D level was highest among group A patients followed by group C patients. It was seen least among group D patients. There was statistically highly significant negative correlation found between GOLD group and 25(OH) vitamin D level with a p value of 0.001 . In another words, patients with more severe symptoms had lower $25(\mathrm{OH})$ vitamin D levels than those with less symptoms.

Table- 6: Comparison of mean vitamin D level according to Pack Year among COPD patients

\begin{tabular}{|c|c|c|c|c|c|}
\hline & & \multicolumn{2}{|c|}{ Vitamin D level(ng/ml) } & \multirow{2}{*}{$\begin{array}{l}\text { ANOVA } \\
\text { 'F' Value }\end{array}$} & \multirow{2}{*}{$\begin{array}{c}\text { Significance } \\
\text { 'p' Value }\end{array}$} \\
\hline Pack year & Number & MEAN & SD & & \\
\hline $0-9$ & 8 & 28.75 & 9.43 & \multirow[t]{4}{*}{3.740} & \multirow[t]{4}{*}{0.015} \\
\hline $10-19$ & 5 & 35.60 & 7.43 & & \\
\hline $20-29$ & 23 & 35.17 & 18.11 & & \\
\hline$>\mathbf{3 0}$ & 38 & 22.24 & 15.60 & & \\
\hline
\end{tabular}

Pack years: On comparing mean 25(OH) vitamin D level according to Pack Year in our study. Most (38) of the patients were having more than 30 pack years followed by 20-29 pack years (n-23). Mean 25(OH) vitamin D level was highest among the patients who had 10-19 \& 20-29 pack years. It was least among the patients who had more than 30 pack year. There was statistically significant negative correlation found between pack year and $25(\mathrm{OH})$ vitamin $\mathrm{D}$ level. $(\mathrm{P}=0.015)$.

Table- 7: Comparison of mean vitamin D level according to 6 Minute Walk Test among COPD patients

\begin{tabular}{|c|c|c|c|c|c|}
\hline \multirow[b]{2}{*}{6 MWT } & \multirow[b]{2}{*}{ Number } & \multicolumn{2}{|c|}{ Vitamin D level (ng/ml) } & \multirow{2}{*}{$\begin{array}{c}\text { ANOVA ' } F \text { ' } \\
\text { Value }\end{array}$} & \multirow{2}{*}{$\begin{array}{c}\text { Significance 'p' } \\
\text { Value }\end{array}$} \\
\hline & & MEAN & SD & & \\
\hline$>400$ meter & 13 & 49.62 & 17.03 & \multirow[t]{5}{*}{35.166} & \multirow[t]{5}{*}{0.001} \\
\hline 399-300 meter & 11 & 40.09 & 8.54 & & \\
\hline 299-200 meter & 8 & 30.00 & 11.25 & & \\
\hline 199-100 meter & 27 & 21.11 & 6.26 & & \\
\hline$<99$ meter & 15 & 11.07 & 5.35 & & \\
\hline
\end{tabular}

6 minute walk test: Out of 74 patients, maximum 27 were in 100-199 meter group. As 6 minute walk test value decreased, 25(OH) vitamin D level also decreased. It was highest among those patients in whom 6 MWT value was above 400 meter and it was minimum among those patients in whom 6 MWT value was below 99 meter. There was statistically highly significant positive correlation between 6 MWT value and $25(\mathrm{OH})$ vitamin D level $(\mathrm{P}=0.001)$. 
Table- 8: Comparison of mean vitamin D level according to ICS Therapy among COPD patients.

\begin{tabular}{|c|c|c|c|c|c|}
\hline \multirow[b]{2}{*}{ ICS Therapy } & \multirow[b]{2}{*}{ Number } & \multicolumn{2}{|c|}{ Vitamin D level (ng/ml) } & \multirow{2}{*}{$\begin{array}{l}\text { Student ' } t \text { ' } \\
\text { Test value }\end{array}$} & \multirow{2}{*}{$\begin{array}{c}\text { Significance } \\
\text { 'p' Value }\end{array}$} \\
\hline & & MEAN & SD & & \\
\hline Yes & 38 & 21.47 & 13.20 & \multirow[t]{2}{*}{3.717} & \multirow[t]{2}{*}{0.001} \\
\hline NO & 36 & 34.61 & 17.05 & & \\
\hline
\end{tabular}

ICS therapy: On comparing mean $25(\mathrm{OH})$ vitamin D level according to ICS in our study. Out of 74 patients, 38 were on ICS. The $25(\mathrm{OH})$ vitamin D level was less among patients on ICS and higher among patients without ICS. There was statistically highly significant difference found in $25(\mathrm{OH})$ vitamin D level according to ICS therapy among COPD patients $(\mathrm{P}=0.001)$. Most of the patients in ICS therapy group had moderate to severe COPD.

\section{Discussion}

The purpose of this study was to find correlation between serum $25(\mathrm{OH})$ vitamin D levels and severity of disease in COPD patients and also to evaluate other factors associated with levels of serum $25(\mathrm{OH})$ vitamin $\mathrm{D}$ levels in COPD patients.

Severity of COPD: In our study, the mean FEV1\% predicted was $50.88 \%$ and the mean $25(\mathrm{OH})$ vitamin D level was $27.86 \mathrm{ng} / \mathrm{ml}$ (Normal $>30 \mathrm{ng} / \mathrm{ml}$ ). In past few years, deficiency of $25(\mathrm{OH})$ vitamin D was observed in patients with declining lung functions [1]. In the NHANES III study, Black et. al found a negative co relationship between $25(\mathrm{OH})$ vitamin D levels in blood and FEV1 and FVC in healthy general population [5].

However, Janssens et. al. in 2010 did a study on exsmoker COPD patients and ex-smoker with normal lung function to find link between serum $25(\mathrm{OH})$ vitamin $\mathrm{D}$ levels with COPD and vitamin $\mathrm{d}$ receptor gene. The mean FEV1\% predicted was $61 \pm 27 \%$ and mean 25 $(\mathrm{OH})$ vitamin $\mathrm{D}$ was $19.9 \pm 8.2 \mathrm{ng} / \mathrm{ml}$. Authors from this study concluded that $25(\mathrm{OH})$ vitamin $\mathrm{D}$ deficiency occurs frequently in COPD and correlates with severity of disease in ex-smoker COPD [16]. A parallel trend was observed in 2011 by Kunisaki et al. in secondary analysis of data from North America.

Where large cohort study of 973 severe COPD patients suggested lower levels of $25(\mathrm{OH})$ vitamin D with mean levels of $25.7 \mathrm{ng} / \mathrm{ml}$ [17]. Our study, which included diagnosed COPD patients and where our primary aim was to correlate severity of COPD with $25(\mathrm{OH})$ vitamin $\mathrm{D}$ levels shows a nearly identical relationship between airways obstruction and $25(\mathrm{OH})$ vitamin D levels. Outcome from our study in Indian scenario, support studies by Janseens et al., Kunisaki KM et al., and Cilingir BM et al. Together these studies provide strong evidence for the relationship between lower serum 25 $(\mathrm{OH})$ vitamin $\mathrm{D}$ levels and decline lung functions in COPD patients and suggest to maintain optimal serum $25(\mathrm{OH})$ vitamin D levels in patients with COPD [16, $17,30]$.

Age Groups: In our study, Mean $25(\mathrm{OH})$ vitamin D level was lower among older patients ( $>70$ years) than younger patients (<69years). However, there was statistically no significant difference in $25(\mathrm{OH})$ vitamin $\mathrm{D}$ levels according to different age groups with a $\mathrm{p}$ value of 0.083 . Previous studies have described $25(\mathrm{OH})$ vitamin $\mathrm{D}$ deficiency as a common phenomenon in elderly populations. [18, 19]. Prior Studies by Jindal et al (2001), Mahesh et al (2009) and Parasuramalu et al (2014) suggested that the prevalence of COPD increases with age, which in turn may lead to decreased mobility and sun exposure [20,21,22]. Also, reduced dietary intake of $25(\mathrm{OH})$ vitamin $\mathrm{D}$ in COPD patients particularly in elderly can explain our outcome [23].

mMRC: There was statistically highly significant negative correlation found between mMRC Dyspnoea grade and $25(\mathrm{OH})$ vitamin $\mathrm{D}$ level with $\mathrm{p}$ value of 0.001 . Recently in a randomized control trial by Sanjari M et al. in 2015, the difference between before and after treatment with $25(\mathrm{OH})$ vitamin D was seen, MMRC was calculated and compared between groups, significant $(p<0.001)$ difference was observed between calcitriol group vs. Placebo [31]. Similarly, Rezk et al noted a significant improvement (p-0.003) in MMRC dyspnoea scale, 1 year after $25(\mathrm{OH})$ vitamin $\mathrm{D}$ replacement [24].

GOLD group: GOLD groups were divided according to disease symptoms and risk. There was statistically highly significant negative correlation found between 
GOLD group and $25(\mathrm{OH})$ vitamin D level with a $\mathrm{p}$ value of 0.001 . In another words, patients with more severe symptoms had lower $25(\mathrm{OH})$ vitamin D levels than those with less symptoms. Similar outcome was observed in a study by Kocabas A et al. in 2013 from Turkey, suggesting that the possibility of $25(\mathrm{OH})$ vitamin D deficiency increased 4.83 times in GOLD group D, when compared to GOLD group A [25].

Pack year: On comparing mean $25(\mathrm{OH})$ vitamin D level according to Pack Year in our study. There was statistically significant negative correlation found between pack year and $25(\mathrm{OH})$ vitamin $\mathrm{D}$ level $(P=0.015)$. Negative correlation of smoking status and lung function decline has been describe earlier [26].

Sanket $\mathrm{S}$ et al in 2016 also found that the chance of having $25(\mathrm{OH})$ vitamin $\mathrm{D}$ deficiency was higher with increased pack year of smoking [27]. There was a similar outcome from a study by Cutillas et al in 2012 [7].

6MWT: As 6 minute walk test value decreased, 25 $(\mathrm{OH})$ vitamin D level also decreased. It was highest among those patients in whom 6 MWT value was above 400 meter and it was minimum among those patients in whom 6 MWT value was below 99 meter. There was statistically highly significant positive correlation between 6 MWT value and $25(\mathrm{OH})$ vitamin D level $(\mathrm{P}=0.001)$. Similarly Moberg et al. in his study reported that 6 min walking distance has significant positive relation with $25(\mathrm{OH})$ vitamin D level $(p=0.01)$ [32].

ICS therapy: On comparing mean $25(\mathrm{OH})$ vitamin D level according to ICS in our study. The $25(\mathrm{OH})$ vitamin D level was less among patients on ICS and higher among patients without ICS. There was statistically highly significant difference found in $25(\mathrm{OH})$ vitamin $\mathrm{D}$ level according to ICS therapy among COPD patients $(\mathrm{P}=0.001)$. Most of the patients in ICS therapy group had moderate to severe COPD. Gupta A et al. in 2011 found that use of inhaled corticosteroid in patients with asthma was associated with $25(\mathrm{OH})$ vitamin D deficiency [28].

Summary- Serum $25(\mathrm{OH})$ Vitamin D levels are efficient and suitable method for assessment of systemic vitamin D levels. The purpose of this study was to find correlation between serum $25(\mathrm{OH})$ vitamin D levels and severity of disease in COPD patients also to evaluate other factors associated with serum $25(\mathrm{OH})$ vitamin $\mathrm{D}$ levels in COPD patients. From the observations we concluded that the majority of COPD patients were males. Decrease serum 25(0H) vitamin D levels were associated with increase airway obstruction, Mean serum $25(\mathrm{OH})$ Vitamin D levels were lower in older patients than younger and related to GOLD group D as compared to GOLD group A. Decrease serum $25(\mathrm{OH})$ vitamin $\mathrm{D}$ were associated with increased pack years, increased frequency of exacerbation in self declared previous year, lower socioeconomic status and in patients on inhaled corticosteroids.

\section{Conclusion}

In our study, we included diagnosed COPD patients and our primary aim was to correlate severity of COPD with $25(\mathrm{OH})$ vitamin $\mathrm{D}$ levels. The results of ours study shows a nearly identical relationship between airways obstruction and $25(\mathrm{OH})$ vitamin D levels. From the observations we concluded that the majority of COPD patients were males. As proved by many studies in ours also the exercise capacity decreased with decreased lung functions and decreased serum $25(\mathrm{OH})$ Vitamin D levels. Taken together, the results of our study and the older ones we can conclude that there is a strong relationship between lower serum $25(\mathrm{OH})$ vitamin $\mathrm{D}$ levels and declining lung functions in COPD patients and suggest to maintain optimal serum $25(\mathrm{OH})$ vitamin D levels in patients with COPD. Future appropriately designed clinical trials are warranted to assess the effect of supplementation of vitamin D on decline in lung function, exercise limitation, morbidity and mortality in patients of COPD.

Limitation- The limitation of the current study was its small sample size and It was also a observational type of study. Large number of baseline data recorded, strictly followed inclusion criteria and use of recommended state of the art machine for measurement of serum $25(\mathrm{OH})$ vitamin d levels were the strength of this study.

\section{Funding: Nil, Conflict of interest: None. Permission of IRB: Yes}

\section{References}

1. Persson LJ, Aanerud M, Hiemstra PS, Hardie JA, Bakke PS, Eagan TM. Chronic obstructive pulmonary disease is associated with low levels of vitamin D. PLoS One.2012;7(6):e38934.doi:10.1371/journal. pone. 0038934. Epub 2012 Jun 21. 
2. Esposito S, Lelii M. Vitamin D and respiratory tract infections in childhood. BMC Infect Dis. 2015 Oct 28; 15: 487. doi: 10.1186/s12879-015-1196-1.

3. Litonjua AA. Childhood asthma may be a consequence of vitamin D deficiency. Curr Opin Allergy Clin Immunol. 2009 Jun; 9(3): 202-7. doi: 10. 1097 /ACI. 0b013e32832b36cd.

4. Ginde AA, Mansbach JM, Camargo CA Jr. Association between serum 25-hydroxyvitamin D level and upper respiratory tract infection in the Third National Health and Nutrition Examination Survey. Arch Intern Med. 2009 Feb 23;169(4):384-90. doi: 10. 1001/archinternmed.2008.560.

5. Black PN, Scragg R. Relationship between serum 25hydroxyvitamin $\mathrm{d}$ and pulmonary function in the third national health and nutrition examination survey. Chest. 2005 Dec;128(6):3792-8.

6. Kocabas A. vitamin d deficiency in copd. M J Resir Care Med. 2013; 187. A2901.

7. Cutillas-Marco E, Fuertes-Prosper A, Grant WB, Morales-Suárez-Varela M. Vitamin D deficiency in South Europe: effect of smoking and aging. Photodermatol Photoimmunol Photomed. 2012 Jun; 28(3):159-61. doi: 10.1111/j.1600-0781.2012. 00649.x.

8. Global Initiative for Chronic Obstructive Lung Disease (GOLD). 2014; Global strategy for the diagnosis, management, and prevention of chronic obstructive pulmonary disease: revised 2014. Available from: http://goldcopd.org/.

9. Prakash C Gupta, Samira Asma. Bidi Smoking and Public Health. Ministry of Health and Family Welfare, Government of India World Health Organization. 2008 March. 66-93.

10. Modified Prasad BG. Social classification of Indian families. J Indian Med Assoc. 2014;51:365.

11. Subramaniam V. Seasonal variation in the incidence of preeclampsia and eclampsia in tropical climatic conditions. BMC Womens Health. 2007 Oct 15;7:18.

12. FLETCHER CM. The clinical diagnosis of pulmonary emphysema; an experimental study. Proc R Soc Med. 1952 Sep;45(9):577-84.
13. Hollis BW, Wagner CL, Drezner MK, Binkley NC. Circulating vitamin D3 and 25-hydroxyvitamin D in humans: An important tool to define adequate nutritional vitamin D status. J Steroid Biochem Mol Biol. 2007 Mar;103(3-5):631-4. Epub 2007 Jan 10.

14. Dawson-Hughes B, Heaney RP, Holick MF, Lips P, Meunier PJ, Vieth R. Estimates of optimal vitamin D status. Osteoporos Int. 2005 Jul;16(7):713-6. Epub 2005 Mar 18.

15. ATS Committee on Proficiency Standards for Clinical Pulmonary Function Laboratories. ATS statement: guidelines for the six-minute walk test. Am J Respir Crit Care Med. 2002 Jul 1;166(1):111-7.

16. Janssens W, Lehouck A, Carremans C, Bouillon R, Mathieu C, Decramer M. Vitamin D beyond bones in chronic obstructive pulmonary disease: time to act. Am J Respir Crit Care Med. 2009 Apr 15;179(8):630-6. doi: 10.1164/rccm.200810-1576PP. Epub 2009 Jan 22.

17. Kunisaki KM, Niewoehner DE, Singh RJ, Connett JE. Vitamin D status and longitudinal lung function decline in the Lung Health Study. Eur Respir J. 2011 Feb; 37(2): 238-43. doi: 10.1183 /09031936. 00146509. Epub 2010 Jul 1.

18. Van der Wielen RP, Lowik MR, van den Berg H, de Groot LC, Haller J. Serum vitamin D concentrations among elderlypeople.EuropeLancert,2005;346:207-210.

19. Lips P. Vitamin D deficiency and secondary hyperparathyroidism in the elderly: consequences for bone loss and fractures and therapeutic implications. Endocr Rev. 2001 Aug; 22(4):477-501.

20. Jindal SK, Aggarwal AN, Chaudhry K, Chhabra SK, D'Souza GA, Gupta D, Katiyar SK, Kumar R, Shah B, Vijayan VK; Asthma Epidemiology Study Group. A multicentric study on epidemiology of chronic obstructive pulmonary disease and its relationship with tobacco smoking and environmental tobacco smoke exposure. Indian J Chest Dis Allied Sci. 2006 Jan-Mar; 48(1):23-9.

21. Mahesh PA, Jayaraj BS, Prahlad ST, Chaya SK, Prabhakar AK, Agarwal AN, Jindal SK. Validation of a structured questionnaire for COPD and prevalence of COPD in rural area of Mysore: A pilot study. Lung India.2009Jul;26(3):63-9.doi:10.4103/09702113.53226. 
22. Parasuramalu BG, Huliraj N, Prashanth Kumar SP; Gangaboraiah, Ramesh Masthi NR, Srinivasa Babu CR. Prevalence of chronic obstructive pulmonary disease and its association with tobacco smoking and environmental tobacco smoke exposure among rural population. Indian J Public Health. 2014 Jan-Mar;58(1): 45-9. doi: 10.4103/0019-557X.128166.

23. J. De Batlle, I. Romieu, J.M. Antó, M. Mendez, E. Rodríguez, E. Balcells. PAC-COPD Study Group: Dietary habits of firstly admitted Spanish COPD patients. Respir Med. 2009;103:1904-1910.

24. Rezk A. effect of vitamin D replacement in COPD. EJCDT. 2015; 64.2 .

25. Kocabaş A, Karagüzel G, Imir N, Yavuzer U, Akçurin S. Effects of vitamin D receptor gene polymorphisms on susceptibility to disease and bone mineral density in Turkish patients with type 1 diabetes mellitus. J Pediatr Endocrinol Metab. 2010 Dec; 23 (12):1289-97.

26. Wang TT, Nestel FP, Bourdeau V, Nagai Y, Wang Q, Liao J, Tavera-Mendoza L, Lin R, Hanrahan JW, Mader S, White JH. Cutting edge: 1, 25dihydroxyvitamin D3 is a direct inducer of antimicrobial peptide gene expression.. J Immunol. 2004 Sep; 54: 64-9.
27. Sanket S. Relation between vitamin d deficiency and severity of COPD. J Clin Diag 2016. 10(1); oc16-9. 173 (5):2909-12.

28. Brehm JM, Celedón JC, Soto-Quiros ME, Avila L, Hunninghake GM, Forno E, Laskey D, Sylvia JS, Hollis BW, Weiss ST, Litonjua AA. Serum vitamin D levels and markers of severity of childhood asthma in Costa Rica. Am J Respir Crit Care Med. 2009 May 1; 179 (9): 765-71. doi: 10.1164/rccm.200808-1361OC. Epub 2009 Jan 29.

29. Kunisaki KM, Niewoehner DE, Singh RJ, Connett JE. Vitamin D status and longitudinal lung function decline in the Lung Health Study. Eur Respir J. 2011 Feb;37(2):238-43. doi: 10.1183/09031936.00146509. Epub 2010 Jul 1.

30. Cilingir BM, Gunbatar H. Relationship between COPD and levels of vitamin D. Dicle medical journal. 2015:42 (2):158-165.

31. Sanjari M, Soltani A. The effect of vitamin D on COPD exacerbation. J Diabetes Metab Disord. 2015; 15 (1):33.

32. Moberg M, Vestbo J. prognostic value of CRP and Vitamin D in severe COPD. The scientific World Journal 2014: 140736, 7. dx. doi. org/10. 1155/ 2014/ 140736 .

\section{How to cite this article?}

Kumar A, Tandon S, Nagdeote ST, Sharma K, Shrikhande A, Gopal K. Serum Vitamin D levels in Chronic Obstructive Pulmonary Disease. Int J Med Res Rev 2017;5(02):128-136. doi:10.17511/ijmrr. 2017.i02.06. 